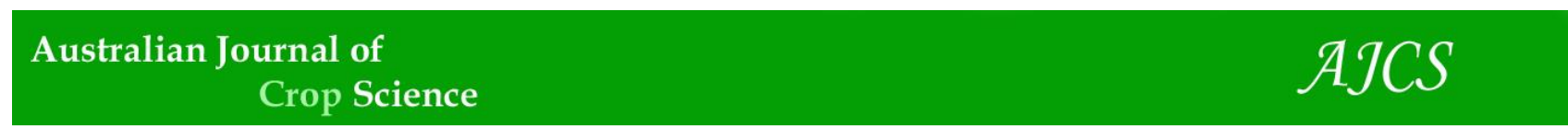

AJCS 11(03):300-307 (2017)

ISSN:1835-2707

doi: 10.21475/ajcs.17.11.03.pne441

\title{
Gas exchange and production of sunflower (Helianthus annuus L.) irrigated with water of different salinity, cationic nature and nitrogen doses
}

\author{
José Raimundo de Sousa Júnior ${ }^{1}$, Geovani Soares de Lima ${ }^{1}$, Hans Raj Gheyi ${ }^{2,4}$, Vera Lúcia Antunes \\ de Lima ${ }^{1,5}$, João Batista dos Santos ${ }^{3}$, Jônatas Raulino Marques de Sousa ${ }^{1}$ and Guilherme de Freitas \\ Furtado ${ }^{1}$
}

${ }^{1}$ Federal University of Campina Grande, Academic Unit of Agricultural Engineering,Campina Grande, 58.109970, Paraíba, Brazil

${ }^{2}$ Federal University of Recôncavo of Bahia, Nucleus of Soil and Water Engineering, Cruz das Almas, 44.380-000,

Bahia, Brazil

${ }^{3}$ Federal University of Campina Grande, Academic Unit of Agricultural Science, Pombal, 58.840-000, Paraíba, Brazil

${ }^{4}$ Fellowof CNPq Reseach Productivity, level 1A, Brazil

${ }^{5}$ Fellow of CNPq Research Productivity, level 1D, Brazil

*Corresponding author: geovanisoareslima@gmail.com

\begin{abstract}
This study aimed to evaluate the gas exchanges and production components of sunflower, cv. BRS 324, as a function of irrigation with water of different salinity levels and cationic nature associated with doses of nitrogen $(\mathrm{N})$. The study was conducted in pots adapted as lysimeters, under field conditions, in an eutrophic Grey Argisol of sandy loam texture. The experimental design was randomized blocks, in $5 \times 5$ factorial scheme, with three replicates, corresponding to five combinations of water salinity and cationic nature - $\mathrm{S}\left(\mathrm{S}_{1}-\mathrm{Control} ; \mathrm{S}_{2}-\mathrm{NaCl} ; \mathrm{S}_{3}-\mathrm{CaCl}_{2} ; \mathrm{S}_{4}-\mathrm{KCl}\right.$ and $\left.\mathrm{S}_{5}-\mathrm{NaCl}+\mathrm{CaCl}_{2}+\mathrm{MgCl}_{2}\right)$ and five $\mathrm{N}$ doses $(50 ; 75 ; 100 ; 125$ and $150 \mathrm{mg}$ of $\mathrm{N} \mathrm{kg}^{-1}$ of soil). Irrigation was applied using water with electrical conductivity - ECw of $0.5 \mathrm{dS} \mathrm{m}^{-1}$ for the control $\left(\mathrm{S}_{1}\right)$ and $5.0 \mathrm{dS}$ $\mathrm{m}^{-1}$ for the other treatments $\left(\mathrm{S}_{2} ; \mathrm{S}_{3} ; \mathrm{S}_{4}\right.$ and $\left.\mathrm{S}_{5}\right)$. Gas exchange through stomatal conductance, transpiration, $\mathrm{CO}_{2}$ assimilation rate, internal $\mathrm{CO}_{2}$ concentration and intrinsic water use efficiency were evaluated and the production components were determined by the internal diameter of the capitulum, the phytomass of the capitulum with achenes and dry matter of the capitulum. The gas exchange of sunflower cv. BRS 324 were significantly influenced, being the biggest decrease due to the variation in the ECw when compared with the cationic nature of irrigation water. Among the evaluated cations, potassium promoted the highest value of stomatal conductance and $\mathrm{CO}_{2}$ assimilation rate. Irrigation with saline water negatively affected the production components of sunflower, regardless of the cation present in the irrigation water.
\end{abstract}

Keywords: Helianthus annuus L., salt stress, water quality, nitrogen.

Abbreviations: $A_{-} \mathrm{CO}_{2}$ assimilation rate; $\mathrm{AW}$ _available water; $\mathrm{Ci}$ internal $\mathrm{CO}_{2}$ concentration; DAS_ days after sowing;

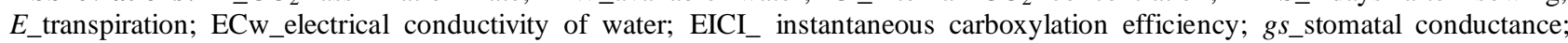
ICD_internal capitulum diameter ; PCA_Phytomass of capitulum with achenes; DP_ phytomass of the capitulum; $\mathrm{pH}_{\mathrm{SP}}-\mathrm{pH}$ of the saturated paste; $\mathrm{EC}_{\mathrm{se}}$ - electrical conductivity of the saturation extract.

\section{Introduction}

Sunflower (Helianthus annuus L.) is an annual dicotyledon plant from the Asteraceae family and the most important cultivated species from the commercial point of view in the genus Helianthus, which comprises 49 species and 19 subspecies, all native to the Americas (Souza, 2010).

Sunflower cultivation has called the interest of farmers, technicians and companies due to the possibility of using its oil as raw material for biodiesel production (Backes et al., 2008). Additionally, sunflower is an excellent alternative not only for biodiesel production, but also for a diversity of applications in different areas, such as production of fodder, silage, oil for human consumption, floriculture and animal feed (Pereira et al., 2008). The oil extracted from its seeds can also be used in the industry of cosmetics, pharmaceuticals, manufacturing of soaps, among various other purposes.

Despite the importance of sunflower in the most varied agroindustrial sectors and its adaptation to the various types of soil and climate in Brazil, the success of its cultivation in semi-arid areas, like many other crops, is conditioned to the use of the technology of irrigation (Oliveira et al., 2010). Thus, the use of irrigation is the only alternative to make agricultural exploitation viable in this region, but most available waters contain relatively moderate contents of salts, which frequently reach electrical conductivity of $5.0 \mathrm{dS} \mathrm{m}^{-1}$ (Cavalcanti et al., 2005). Thus, the use of these water sources with high concentration of salts (especially $\mathrm{Na}^{+}$) in agriculture compromises the quality of harvested product and of the soil. As a consequence of this process, there is a loss of 
the productive capacity of the soils and large socioeconomic damages (Neves et al., 2009).

One of the main factors that limit plant growth and yield is salinity, and this limitation is due to the fact that, under saline conditions, there is a reduction in the availability of water to the plants, because of the decrease in the osmotic potential of the soil solution and, therefore, plants tend to spend more energy to absorb water and nutrients (Leonardo et al., 2003). In addition, salinity can cause nutritional imbalance due to the excess of sodium in the soil solution, leading to disorder in the absorption of nutrients, particularly affecting the contents of $\mathrm{Ca}, \mathrm{Mg}$ and $\mathrm{K}$ in the plant (Wanderley et al., 2010).

In order to minimize the effects of salinity on sunflower growth and yield, various strategies have been studied, particularly the use of nitrogen $(\mathrm{N})$ fertilizers (Biscaro et al., 2008; Nobre et al., 2010; Nobre et al., 2011). Since N is a macronutrient required in large amount by the agricultural crops, it is among the main management techniques (Miller \& Cramer, 2004) because of its participation in the formation of protein, amino acids and other compounds important for plant metabolism (Barhoumi et al., 2010). Besides this $\mathrm{N}$ reduces the deleterious effects of the stress, which can lead to an increase in the tolerance of plant to salinity.

Although there arestudies on the sunflower crop irrigated with saline waters and nitrogen fertilization but studies on the use of waters of distinct cationic nature associated to fertilization with nitrogenare still incipient.Thus, it is imperative to develop new studies that explore the effects of the different types of cations present in the irrigation water in order to identify the cation and the dose of $\mathrm{N}$ that cause less damage to the physiological and productive aspects of the sunflower to make possible the cultivation of this oilseed crop in the northeast of Brazil.

In this context, this study aimed to evaluate the gas exchanges and production components of sunflower, cv. BRS 324 , as a function of irrigation water salinity associated with cationic nature and $\mathrm{N}$ doses.

\section{Results and Discussion}

\section{Effect of salinity and the cationic nature of irrigation water and nitrogen doses on physiology of sunflower}

According to the summary of the analysis of variance shown in Table 1, there was significant influence of the factor salinity ( $\mathrm{S})$ on the variables stomatal conductance $(g s)$ and $\mathrm{CO}_{2}$ assimilation rate $(A)$. For the factor $\mathrm{N}$ doses (ND) and for the interaction between factors (S x ND), there was no significant ( $p>0.05)$ effect on any of the studied variables, indicating that the plants exhibited similar behavior when subjected to the different $\mathrm{N}$ doses. Sousa et al. (2012a), evaluating the gas exchange in jatropha irrigated with saline water prepared with $\mathrm{NaCl}$ ( $\mathrm{ECw}$ : 0.6 and $2.4 \mathrm{dS} \mathrm{m}^{-1}$ ), also verified that there was no significant difference on transpiration and internal $\mathrm{CO}_{2}$ concentration.

For the data of $g s$ at 56 DAS, based on the comparison of means (Fig1A), there was significant difference between the treatments; plants irrigated with water $\mathrm{S}_{1}$ (Control - ECw of $0.5 \mathrm{dS} \mathrm{m}^{-1}$ ) were statistically superior to those in the other treatments irrigated using water with cationic nature of $\mathrm{Na}^{+}$, $\mathrm{Ca}^{2+}$ and $\mathrm{Na}^{+}+\mathrm{Ca}^{2+}+\mathrm{Mg}^{2+}\left(\mathrm{S}_{2} ; \mathrm{S}_{3}\right.$ and $\mathrm{S}_{5}$, respectively), except for plants irrigated with water containing $\mathrm{K}^{+}\left(\mathrm{S}_{4}\right)$ in its composition. However, comparing the means obtained in the different treatments, it is noted that plants subjected to irrigation using waters $\mathrm{S}_{2}, \mathrm{~S}_{3}$ and $\mathrm{S}_{4}\left(\mathrm{Na}^{+}, \mathrm{Ca}^{2+}\right.$ and $\mathrm{K}^{+}$, respectively) did not differ statistically. The lowest value of gs occurred for irrigation water composed of $\mathrm{Na}^{+}+\mathrm{Ca}^{2+}+\mathrm{Mg}^{2+}$ $\left(S_{5}\right)$; however, it did not differ from the treatments $S_{2}$ and $\mathrm{S}_{3}\left(\mathrm{Na}^{+}\right.$and $\mathrm{Ca}^{+2}$, respectively). The results of this study corroborate those found by Lima (2014), who studied the effects of salinity and cationic nature of the irrigation water $\left(\mathrm{Na}^{+} ; \mathrm{Ca}^{2+} ; \mathrm{Na}^{+}+\mathrm{Ca}^{2+} ; \mathrm{K}^{+}\right.$and $\left.\mathrm{Na}^{+}+\mathrm{Ca}^{2+}+\mathrm{Mg}^{2+}\right)$ on castor bean morphophysiology and production, and observed that plants irrigated with water of low salinity and plants irrigated with water containing $\mathrm{K}^{+}$in its composition showed higher stomatal conductance. Graciano et al. (2011) studying the photosynthetic capacity of peanut plants cv. BR 1 submitted to salt stress with water prepared by the addition of $\mathrm{NaCl}$ (ECw: 1.0 to $8.5 \mathrm{dS} \mathrm{m}^{-1}$ ), also verified a reduction in stomatal conductance values.

According to Table 1, the summary of the analysis of variance for the contrasts of means referring to the stomatal conductance, there was significant effect for the contrast $\hat{y}_{1}\left(S_{1}\right.$ vs $S_{2} ; S_{3} ; S_{4}$ and $\left.S_{5}\right)$ at 56 DAS. Based on the estimate of the mean (Table 2), it is noted that sunflower plants subjected to the treatment $S_{1}$, with lowest level of water salinity $\left(0.5 \mathrm{dS} \mathrm{m}^{-1}\right)$, showed increment in $g s$ of $0.41 \mathrm{~mol}$ of $\mathrm{H}_{2} \mathrm{O} \mathrm{m}^{-2} \mathrm{~s}^{-1}$, in comparison to the treatments irrigated with water of different cationic nature $\left(S_{2}, S_{3}, S_{4}\right.$ and $\left.S_{5}\right)$ with $\mathrm{ECw}$ of $5.0 \mathrm{dS} \mathrm{m}^{-1}$., The negative effect on the $g s$ of plants in the treatments $S_{2}, S_{3}, S_{4}$ and $S_{5}$ results from the saline nature of the irrigation water, because the excess of salts that are present in the soil solution causes alteration in the osmotic potential, directly affecting water absorption by plants (Lima, 2014).

The closure of stomata may also be a consequence of the lower leaf water potential that these plants may present due to the salinity of the irrigation water to which they were submitted, as well as the reduction of the hydraulic conductivity of the roots. This fact exerts a detrimental effect on the stomatal opening process of plants, by increasing the resistance to $\mathrm{CO}_{2}$ diffusion in the intercellular spaces or in the substomatic chamber, providing a reduction in the normal $\mathrm{CO}_{2}$ flow towards the carboxylation site (Britto \& Kronzucker, 2002; Flexas et al., 2008; Kusvuran, 2012). According to the test of comparison of means (Figure 1B), the $\mathrm{CO}_{2}$ assimilation rate $(A)$ was significantly influenced by the treatments with water of different ionic composition; at 56 DAS, plants irrigated with water $\mathrm{S}_{1}$ (Control) showed higher $\mathrm{CO}_{2}$ assimilation rate, in comparison to those irrigated using water with cationic nature of $\mathrm{Na}^{+}, \mathrm{Ca}^{2+}$ and $\mathrm{Na}^{+}+\mathrm{Ca}^{2+}+\mathrm{Mg}^{2+}\left(\mathrm{S}_{2} ; \mathrm{S}_{3}\right.$ and $\mathrm{S}_{5}$ respectively); in comparison to the treatments irrigated with water containing $\mathrm{K}^{+}\left(\mathrm{S}_{4}\right)$ in its composition, there was no significant difference. However, when plants irrigated with water containing $\mathrm{K}^{+}\left(\mathrm{S}_{4}\right)$ were compared with those of the other treatments irrigated using water with cationic nature of $\mathrm{Na}^{+}, \mathrm{Ca}^{2+}$ and $\mathrm{Na}^{+}+\mathrm{Ca}^{2+}+\mathrm{Mg}^{2+}$ $\left(\mathrm{S}_{2} ; \mathrm{S}_{3}\right.$ and $\mathrm{S}_{5}$, respectively) regarding $A$, there was no significant difference, thus pointing to a possible action similar to that of these salts on the $\mathrm{CO}_{2}$ assimilation rate of sunflower plants.

Additionally, sunflower plants studied at 56 DAS under irrigation with water of the treatments $S_{1}$ and $S_{4}$ (Figure 1B) stood out with the highest $\mathrm{CO}_{2}$ assimilation rates (21.48 and $14.57 \mu \mathrm{mol} \mathrm{m} \mathrm{m}^{-2}$, respectively).In relation to the other treatments $\left(\mathrm{S}_{2} ; \mathrm{S}_{3}\right.$ and $\left.\mathrm{S}_{5}\right)$, the $\mathrm{CO}_{2}$ assimilation rates followed the same trend of the stomatal conductance observed in Figure 1A. Although plants were subjected to the stress caused by the salts present in the irrigation water, according to Taiz \& Zeiger (2013), the values of Aobtained are satisfactory, because sunflower is a $\mathrm{C}_{3}$ plant and the $\mathrm{CO}_{2}$ assimilation rates of these plants vary between 10 and 20 $\mu \mathrm{mol} \mathrm{m} \mathrm{m}^{-2} \mathrm{~s}^{-1}$. 
Table 1. Summary of the analysis of variance for stomatal conductance $(g s)$, internal $\mathrm{CO}_{2}$ concentration $(\mathrm{Ci})$, transpiration $(E)$, $\mathrm{CO}_{2}$ assimilation rate $(A)$ and intrinsic water use efficiency (WUE) of sunflower, cv. BRS 324, at 56 days after emergence, cultivated under different types of salinity and nitrogen doses.

\begin{tabular}{|c|c|c|c|c|c|c|}
\hline \multirow{2}{*}{ Source of variation/Contrasts } & \multirow{2}{*}{$\mathrm{DF}$} & \multicolumn{5}{|c|}{ Mean square } \\
\hline & & $g s^{1}$ & $C i^{1}$ & $E^{1}$ & $A^{1}$ & WUE $^{1}$ \\
\hline Blocks & 2 & $0.1398^{\mathrm{ns}}$ & $34228.9881^{*}$ & $105.5749^{\mathrm{ns}}$ & $800.6651^{* *}$ & $11.2901^{*}$ \\
\hline $\begin{array}{l}\text { Cationic composition of water } \\
(\mathrm{CCW})\end{array}$ & 4 & $0.7160^{* *}$ & $14544.6018^{\mathrm{ns}}$ & $31.9594^{\mathrm{ns}}$ & $286.8949^{*}$ & $2.0092^{\mathrm{ns}}$ \\
\hline$\hat{y}_{1}$ & 1 & $2.0295^{* *}$ & $37862.6242^{\mathrm{ns}}$ & $24.8601^{\mathrm{ns}}$ & $993.3196^{*}$ & $3.4397^{\mathrm{ns}}$ \\
\hline$\hat{\mathrm{y}}_{2}$ & 1 & $0.0011^{\mathrm{ns}}$ & $16661.6333^{\mathrm{ns}}$ & $0.2707^{\mathrm{ns}}$ & $10.0688^{\mathrm{ns}}$ & $0.1370^{\mathrm{ns}}$ \\
\hline$\hat{\mathrm{y}}_{3}$ & 1 & $0.4440^{\mathrm{ns}}$ & $187.5000^{\mathrm{ns}}$ & $3.8664^{\mathrm{ns}}$ & $19.2800^{\mathrm{ns}}$ & $0.0456^{\mathrm{ns}}$ \\
\hline$\hat{\mathrm{y}}_{4}$ & 1 & $0.8046^{\mathrm{ns}}$ & $3618.0500^{\mathrm{ns}}$ & $0.7119^{\mathrm{ns}}$ & $95.7031^{\mathrm{ns}}$ & $0.5401^{\mathrm{ns}}$ \\
\hline Nitrogen doses (DN) & 4 & $0.1270^{\mathrm{ns}}$ & $8025.1895^{\mathrm{ns}}$ & $51.5535^{\mathrm{ns}}$ & $113.8312^{\mathrm{ns}}$ & $2.5606^{\mathrm{ns}}$ \\
\hline Interaction $(\mathrm{CCW} \times \mathrm{DN})$ & 16 & $0.0883^{\mathrm{ns}}$ & $6792.0260^{\mathrm{ns}}$ & $48.6879^{\mathrm{ns}}$ & $36.7252^{\mathrm{ns}}$ & $1.9059^{\mathrm{ns}}$ \\
\hline Residual & 48 & 0.0851 & 6484.6236 & 39.9069 & 46.5103 & 1.2581 \\
\hline $\mathrm{CV}$. & & 16.57 & 18.42 & 18.34 & 14.88 & 19.93 \\
\hline
\end{tabular}

${ }_{1}=$ Control; $\mathrm{S}_{2}=\mathrm{NaCl} ; \mathrm{S}_{3}=\mathrm{CaCl}_{2} ; \mathrm{S}_{4}=\mathrm{KCl} ; \mathrm{S}_{5}=\mathrm{NaCl}+\mathrm{CaCl}_{2}+\mathrm{MgCl}_{2} ; \hat{\mathrm{y}}_{1}\left(\mathrm{~S}_{1}\right.$ vs $\left.\mathrm{S}_{2} ; \mathrm{S}_{3} ; \mathrm{S}_{4} ; \mathrm{S}_{5}\right) ; \hat{\mathrm{y}}_{2}\left(\mathrm{~S}_{2}\right.$ vs $\left.\mathrm{S}_{3}\right) ; \hat{\mathrm{y}}_{3}\left(\mathrm{~S}_{2}\right.$ vs $\left.\mathrm{S}_{4}\right) ; \hat{\mathrm{y}}_{4}\left(\mathrm{~S}_{5}\right.$ vs $\left.\mathrm{S}_{2} ; \mathrm{S}_{3} ; \mathrm{S}_{4}\right) ; \mathrm{DF}-\mathrm{Degrees}_{2}$ of freedom; CV Coefficient of variation; $(*)$ and $(* *)$ Signific ant at 0.05 and 0.01 probability levels; (ns) Not significant; $\left({ }^{1}\right)$ data transformed to $\sqrt{\mathrm{x}}$.
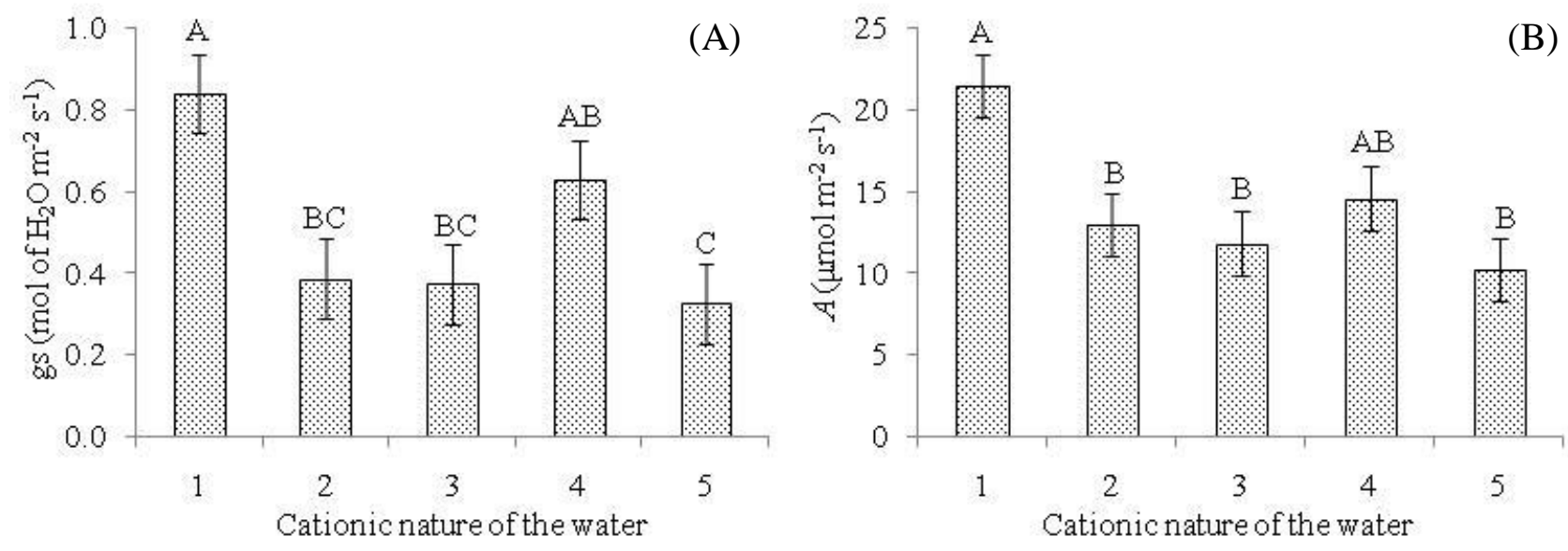

Fig 1. Stomatal conductance $(g s)(\mathrm{A})$ and $\mathrm{CO}_{2}$ assimilation rate $(A)$ (B)of sunflower, cv. BRS 324, as a function of the salinity and cationic nature of the irrigation water at 56 DAS. $1=\mathrm{Control} ; 2=\mathrm{NaCl} ; 3=\mathrm{CaCl}_{2} ; 4=\mathrm{KCl} ; 5=\mathrm{NaCl}+\mathrm{CaCl}_{2}+\mathrm{MgCl}_{2}$; Means followed by different letters indic ate that the treatments differ by Tukey test, $\mathrm{p}<0.05$. Bars represent the standard error of the mean $(\mathrm{n}=3)$.

Table 2. Estimate of mean for stomatal conductance $(\mathrm{gs})$, internal $\mathrm{CO}_{2}$ concentration $(\mathrm{CI})$, transpiration $(E), \mathrm{CO}_{2}$ assimilation rate $(A)$ and intrinsic water use efficiency (WUE) at 56 days after emergence of sunflower, cv. BRS 324, cultivated under different types of salinity and nitrogen doses.

\begin{tabular}{llllll}
\hline Source of & \multicolumn{3}{c}{ Estimation of mean } & & \\
\cline { 2 - 7 } variation & $g s$ & $C i$ & $\mathrm{~ns}$ & 9.09 & WUE \\
\hline$\hat{y}_{1}$ & 0.41 & $\mathrm{~ns}$ & $\mathrm{~ns}$ & $\mathrm{~ns}$ & $\mathrm{~ns}$ \\
$\hat{\mathrm{y}}_{2}$ & $\mathrm{~ns}$ & $\mathrm{~ns}$ & $\mathrm{~ns}$ & $\mathrm{~ns}$ & $\mathrm{~ns}$ \\
$\hat{\mathrm{y}}_{3}$ & $\mathrm{~ns}$ & $\mathrm{~ns}$ & $\mathrm{~ns}$ & $\mathrm{~ns}$ & $\mathrm{~ns}$ \\
$\hat{\mathrm{y}}_{4}$ & $\mathrm{~ns}$ & $\mathrm{~ns}$ & $\mathrm{~ns}$ & $\mathrm{~ns}$
\end{tabular}

$\hat{y}_{1}\left(\mathrm{~S}_{1}\right.$ vs $\left.\mathrm{S}_{2} ; \mathrm{S}_{3} ; \mathrm{S}_{4} ; \mathrm{S}_{5}\right) ; \hat{y}_{2}\left(\mathrm{~S}_{2}\right.$ vs $\left.\mathrm{S}_{3}\right) ; \hat{y}_{3}\left(\mathrm{~S}_{2}\right.$ vs $\left.\mathrm{S}_{4}\right) ; \hat{y}_{4}\left(\mathrm{~S}_{5}\right.$ vs $\left.\mathrm{S}_{2} ; \mathrm{S}_{3} ; \mathrm{S}_{4}\right) ;(\mathrm{ns})$ not significant; $\mathrm{S}_{1}=\mathrm{Control} ; \mathrm{S}_{2}=\mathrm{NaCl} ; \mathrm{S}_{3}=\mathrm{CaCl} \mathrm{Cl}_{2} ;$ $\mathrm{S}_{4}=\mathrm{KCl} ; \mathrm{S}_{5}=\mathrm{NaCl}+\mathrm{CaCl}_{2}+\mathrm{MgCl}_{2}$. 

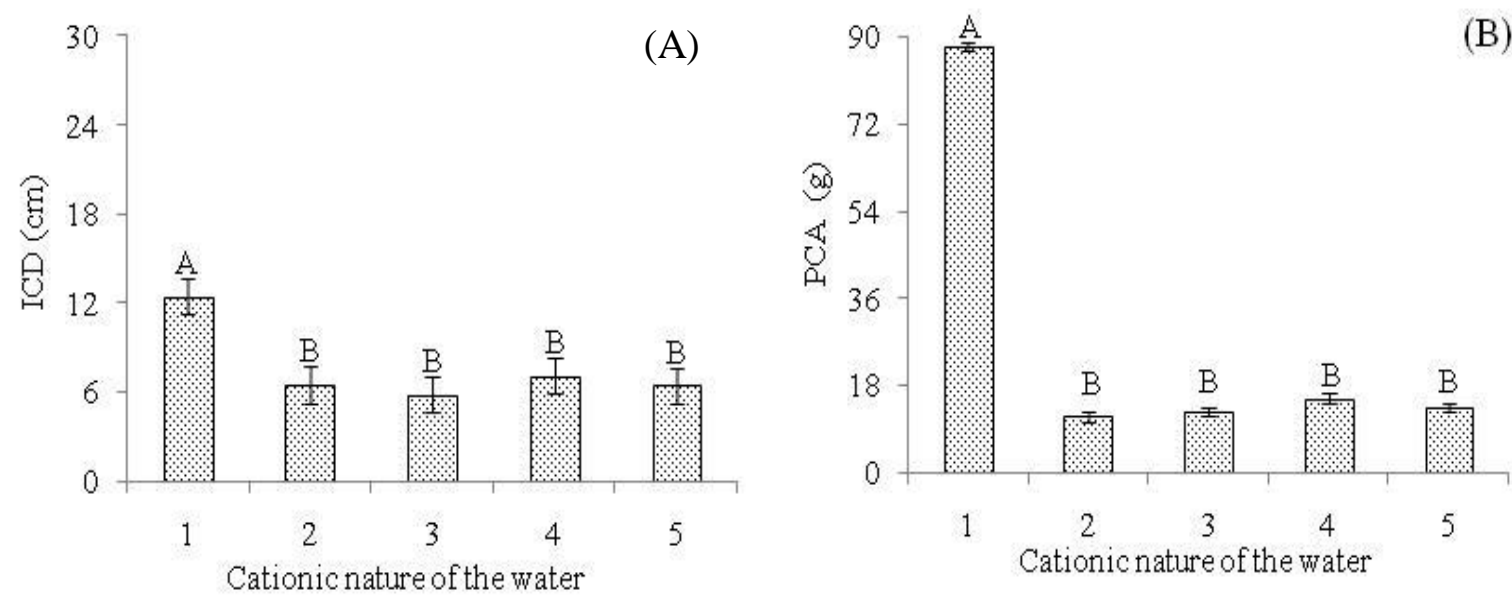

Fig 2. Internal capitulum diameter - ICD (A) and phytomass of the capitulum with achenes - PCA (B) of sunflower, cv. BRS 324 , as a function of the salinity and cationic nature of the water. $1=$ Control; $2=\mathrm{NaCl} ; 3=\mathrm{CaCl}_{2} ; 4=\mathrm{KCl} ; 5=\mathrm{NaCl}+\mathrm{CaCl}_{2}+\mathrm{MgCl}_{2} ; \mathrm{Means}_{\text {followed by }}$ different letters indicate that the treatments differ by Tukey test, $\mathrm{p}<0.05$. Bars represent the standard error of the mean $(\mathrm{n}=3)$.

Table 3. Summary of the analysis of variance for internal capitulum diameter (ICD), phytomass of the capitulum with achenes (PCA) and dry phytomass of the capitulum (DPC) of sunflower plants, cv. BRS 324, cultivated under different types of salinity and nitrogen doses.

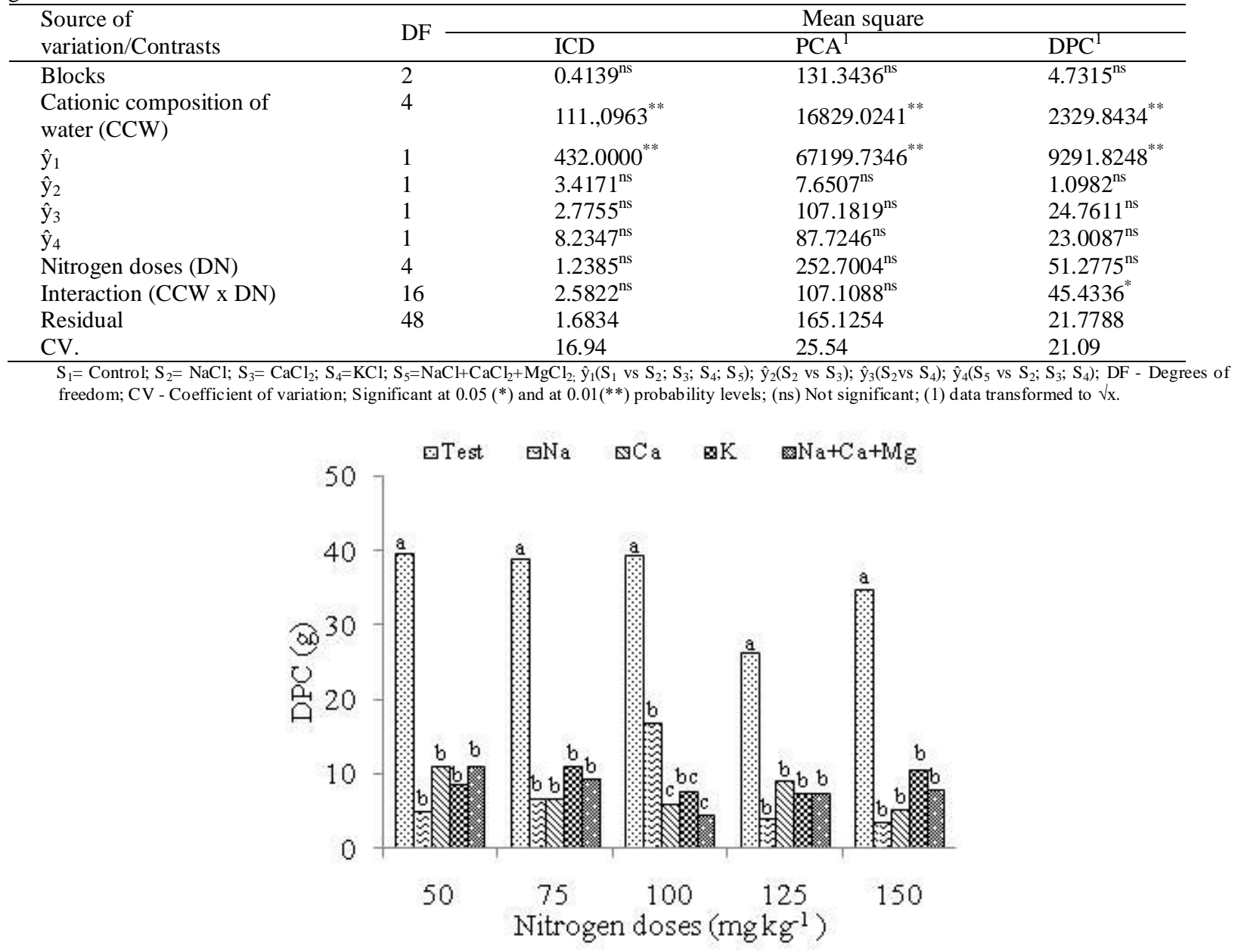

Fig 3. Dry phytomass of the capitulum - DPC of sunflower, cv. BRS 324, as a function of the salinity and cationic nature of the water and nitrogen doses. $1=$ Control; $2=\mathrm{NaCl} ; 3=\mathrm{CaCl}_{2} ; 4=\mathrm{KCl} ; 5=\mathrm{NaCl}+\mathrm{CaCl}_{2}+\mathrm{MgCl}_{2}$; Means followed by different letters indicate that the treatments differed by Tukey test, $\mathrm{p}<0.05$. 
Table 4. Estimate of mean for internal capitulum diameter (ICD), phytomass of the capitulum with achenes (PCA) and dry phytomass of the capitulum (DPC) of sunflower plants, cv. BRS 324, cultivated under different types of salinity and nitrogen doses.

\begin{tabular}{llll}
\hline Source of & & Estimation of mean & \\
\cline { 2 - 4 } variation & DCI & FCA & FSCa \\
\hline$\hat{y}_{1}$ & 6.00 & 74.83 & 27.82 \\
$\hat{y}_{2}$ & $n s$ & $n s$ & $n s$ \\
$\hat{y}_{3}$ & $n s$ & $n s$ & $n s$ \\
$\hat{y}_{4}$ & $n s$ & $n s$ & $n s$ \\
\hline
\end{tabular}

$\hat{y}_{1}\left(S_{1}\right.$ vs $\left.\mathrm{S}_{2} ; \mathrm{S}_{3} ; \mathrm{S}_{4} ; \mathrm{S}_{5}\right) ; \hat{y}_{2}\left(\mathrm{~S}_{2}\right.$ vs $\left.\mathrm{S}_{3}\right) ; \hat{y}_{3}\left(\mathrm{~S}_{2}\right.$ vs $\left.\mathrm{S}_{4}\right) ; \hat{y}_{4}\left(\mathrm{~S}_{5}\right.$ vs $\left.\mathrm{S}_{2} ; \mathrm{S}_{3} ; \mathrm{S}_{4}\right) ;\left(\right.$ ns) not significant; $\mathrm{S}_{1}=$ Control; $\mathrm{S}_{2}=\mathrm{NaCl}_{3} \mathrm{~S}_{3}=\mathrm{CaCl}_{2} ;$ $\mathrm{S}_{4}=\mathrm{KCl} ; \mathrm{S}_{5}=\mathrm{NaCl}+\mathrm{CaCl}_{2}+\mathrm{MgCl}_{2}$

Table 5. Physical and chemical characteristics of the soil used in the experiment.

\begin{tabular}{|c|c|c|c|c|c|c|c|c|c|c|}
\hline \multirow{4}{*}{$\begin{array}{l}\text { Density } \\
\left(\mathrm{kg} \mathrm{dm}^{-3}\right)\end{array}$} & \multirow{3}{*}{$\begin{array}{l}\text { Total } \\
\text { porosity } \\
(\%)\end{array}$} & \multirow{2}{*}{\multicolumn{2}{|c|}{ Water content $(\%)$}} & \multirow{3}{*}{$\begin{array}{l}\text { Available } \\
\text { water } \\
(\%) \\
\end{array}$} & \multicolumn{4}{|c|}{ Exchange complex } & \multirow[b]{2}{*}{$\mathrm{pH}_{\mathrm{sp}}$} & \multirow{3}{*}{$\begin{array}{l}\mathrm{EC}_{\mathrm{se}} \\
\quad\left(\mathrm{dS} \mathrm{m}^{-1}\right)\end{array}$} \\
\hline & & & & & $\mathrm{Ca}^{2+}$ & $\mathrm{Mg}^{2+}$ & $\mathrm{Na}^{+}$ & $\mathrm{K}^{+}$ & & \\
\hline & & $0.33 \mathrm{~atm}$ & $15.0 \mathrm{~atm}$ & & \multicolumn{4}{|c|}{$\ldots \ldots \ldots\left(\mathrm{cmol}_{\mathrm{c}} \mathrm{kg}^{-1}\right) \ldots \ldots \ldots \ldots$} & - & \\
\hline & 57.93 & 14.00 & 4.87 & 9.13 & 1.52 & 1.95 & 0.38 & 0.07 & 4.84 & 0.20 \\
\hline
\end{tabular}

Table 2 shows the contrasts of means for the $\mathrm{CO}_{2}$ assimilation rate $(A)$ at 56 DAS. There was significant effect only for the contrast $\hat{y}_{1}\left(S_{1} v s S_{2} ; S_{3} ; S_{4}\right.$ and $\left.S_{5}\right)$ through the estimate of mean presented in Table 2 . It is noted that plants subjected to the treatment $\mathrm{S}_{1}$ (control - ECW of $0.5 \mathrm{dS} \mathrm{m}^{-1}$ ) increased the rate of $A$ by $9.09 \mu \mathrm{mol} \mathrm{m} \mathrm{m}^{-2} \mathrm{~s}^{-1}$ in relation to plants cultivated under irrigation with water of different ionic composition, $\mathrm{S}_{2} ; \mathrm{S}_{3} ; \mathrm{S}_{4}$ and $\mathrm{S}_{5} \quad\left(\mathrm{Na}^{+} ; \mathrm{Ca}^{2+} ; \mathrm{K}^{+}\right.$and $\left.\mathrm{Na}^{+}+\mathrm{Ca}^{2+}+\mathrm{Mg}^{2+}\right)$ and $\mathrm{ECw}$ of $5.0 \mathrm{dS} \mathrm{m} \mathrm{m}^{-1}$. The high saline concentration of the irrigation water causes reduction in the water potential of the soil and, as a consequence, the stomata close, thus reflecting in low $\mathrm{CO}_{2}$ assimilation rate (Gurgel et al., 2003). This decline in the $\mathrm{CO}_{2}$ assimilation rate of sunflower plants is also related to the damage in the photosynthetic apparatus and /or in the enzymatic system of $\mathrm{CO}_{2}$ fixation (Kurban et al., 1999), due to the irrigation with water of different cationic nature and by the variation in $\mathrm{ECw}$ levels. Similar results were also verified in cotton (Meloni et al., 2003) and jatropha (Sousa et al., 2012b).

Effect of salinity and the cationic nature of irrigation water and nitrogen doses on production components of sunflower

According to Table 3, which shows the results of the analysis of variance for the internal capitulum diameter (ICD), phytomass of the capitulum with achenes (PCA) and dry phytomass of the capitulum (DPC) of sunflower, there was significant effect of the types of water salinity (S) on all studied variables. For the factor $\mathrm{N}$ doses (ND), there was no significant influence for any of the studied variables, while the interaction (S x ND) showed to significance only for the dry phytomass of the capitulum (DPC). Nobre et al. (2011) evaluating the production of sunflower cv. Embrapa 122 / V2000 cultivated under different irrigation water salinity levels (ECw: 0.5 to $4.9 \mathrm{dS} \mathrm{m}^{-1}$, prepared with addition of $\mathrm{NaCl}$ ) and nitrogen fertilization rates, also observed no interaction between these factors for any production variable evaluated. Based on Fig2A, the internal capitulum diameter (ICD) differed statistically. According to the test of comparison of means, in plants irrigated with water $S_{1}($ Control), the ICD was significantly superior to that obtained by plants irrigated with waters of different cationic nature, $S_{2}, S_{3}, S_{4}$ and $S_{5}$, with reductions in the capitulum diameter of $47.89,53.31,43.01$ and $48.42 \%$, respectively.

According to the summary of the analysis of the contrasts of means for the variable ICD (Table 3), there was significant effect for the contrast $\hat{y}_{1}\left(S_{1} v s S_{2} ; S_{3} ; S_{4}\right.$ and $\left.S_{5}\right)$ and, based on the estimate of mean (Table 4), plants irrigated in the treatment $S_{1}$, with lowest level of water salinity (ECW of 0.5 $\mathrm{dS} \mathrm{\textrm {m } ^ { - 1 }}$ ), showed superior ICD, with mean of $6.0 \mathrm{~cm}$ higher in relation to the plants that received water of different cationic nature, $\mathrm{Na}^{+} ; \mathrm{Ca}^{2+} ; \mathrm{K}^{+}$and $\mathrm{Na}^{+}+\mathrm{Ca}^{2+}+\mathrm{Mg}^{2+}\left(\mathrm{S}_{2} ; \mathrm{S}_{3} ; \mathrm{S}_{4}\right.$ and $\mathrm{S}_{5}$, respectively) with $\mathrm{ECw}$ of $5.0 \mathrm{dS} \mathrm{m}^{-1}$. For ICD, in the other contrasts of mean, $\hat{y}_{2}\left(S_{2}\right.$ versus $\left.S_{3}\right), \hat{y}_{3}\left(S_{2}\right.$ versus $\left.S_{4}\right)$ and $\hat{y}_{4}$ $\left(\mathrm{S}_{5}\right.$ versus $\left.\mathrm{S}_{2} ; \mathrm{S}_{3} ; \mathrm{S}_{4}\right)$, there was no significant effect. Excess of salts in water, independently of their cationic nature, cause damage to various physiological and biochemical processes such as respiration, photosynthesis, protein synthesis and lipid metabolism, and may also lead the plant to a state of water stress with loss of water to the external environment and to suffer from toxicity, which will result in serious damage to the growth and production of plants (Esteves\& Suzuki, 2008). Corroborating with the results obtained Nobre et al. (2011) found that the effect of irrigation with water of different saline levels and nitrogen rates on sunflower growth and flowering, decreased both internal and external diameterof capitulum. According to Figure2B, the phytomass of the capitulum with achenes (PCA) of the plants differed significantly due to the use of water with different cationic nature, and the highest value $(88.03 \mathrm{~g})$ was obtained using water of the treatment $S_{1}$ (control). However, plants irrigated with water of the treatments $\mathrm{S}_{2}, \mathrm{~S}_{3}, \mathrm{~S}_{4}$ and $\mathrm{S}_{5}$ obtained PCA of $11.51,12.52,15.29$ and $13.46 \mathrm{~g}$, respectively, i.e., reductions of $86.92,85.77,82.62$ and $84.70 \%$, in comparison to the control $\left(\mathrm{S}_{1}\right)$. Based on the summary of the analysis of variance and the contrasts of means (Table 3 ) referring to the PCA, there was significant effect for the contrast $\hat{y}_{1}\left(\mathrm{~S}_{1} \mathrm{vs} \mathrm{S}_{2}\right.$; $\mathrm{S}_{3} ; \mathrm{S}_{4}$ and $\mathrm{S}_{5}$ ). According to the estimate of mean referring to the PCA (Table 4), sunflower plants subjected to the treatment $S_{1}$,i.e. irrigated with water of lowest salinity level $\left(0.5 \mathrm{dS} \mathrm{m} \mathrm{m}^{-1}\right)$, were superior to those under irrigation with waters of different types of cationic nature, $\mathrm{Na}^{+}, \mathrm{Ca}^{2+} ; \mathrm{K}^{+}$and $\mathrm{Na}^{+}+\mathrm{Ca}^{2+}+\mathrm{Mg}^{2+}\left(\mathrm{S}_{2} ; \mathrm{S}_{3} ; \mathrm{S}_{4}\right.$ and $\mathrm{S}_{5}$, respectively), and $\mathrm{ECw}$ of $5.0 \mathrm{dS} \mathrm{m}^{-1}$, showing a mean increment of $74.83 \mathrm{~g}$ in the PCA. According to Lima (2014), the effect caused by salt stress of the irrigation water is more associated with the irrigation water $\mathrm{ECw}$ than with the cationic nature. The decline in sunflower PCA as a function of water salinity can also be attributed to the osmotic stress caused by the reduction of external water potential and the ionic effect caused by the accumulation of ions in plant tissues (Munns\& Tester, 2008), causing a reduction in the photosynthetic rate and energy deviation destined for the activation and maintenance of plant metabolic activity (Munns et al., 2002). Marenco Centeno et 
al. (2014), studying the effect of irrigation water salinity and nitrogen fertilization on the production of sunflower, cv. Embrapa 122-V2000, and evaluating the influence of irrigation with saline water with $\mathrm{ECw}$ from 0.7 to $4.7 \mathrm{dS} \mathrm{m}^{-1}$, observed the highest phytomass of the capitulum (130.24 g) in plants under $\mathrm{ECw}$ of $0.7 \mathrm{dS} \mathrm{\textrm {m } ^ { - 1 }}$, while the lowest value $(51.28 \mathrm{~g})$ occurred in plants subjected to $\mathrm{ECw}$ of $4.7 \mathrm{dS} \mathrm{m}^{-1}$, indicating a reduction of $60.63 \%$. For dry phytomass of the capitulum - DPC (Figure 3) and based on the interaction between the cationic nature of the water and $\mathrm{N}$ doses, the highest values of PCA were obtained in plants irrigated by the treatment $\mathrm{S}_{1}$ (Control) at all $\mathrm{N}$ doses, significantly differing from the other plants irrigated with water of different cationic nature, $\mathrm{Na}^{+}, \mathrm{Ca}^{2+} ; \mathrm{K}^{+}$and $\mathrm{Na}^{+}+\mathrm{Ca}^{2+}+\mathrm{Mg}^{2+}$ $\left(\mathrm{S}_{2} ; \mathrm{S}_{3} ; \mathrm{S}_{4}\right.$ and $\mathrm{S}_{5}$, respectively). Also based on Figure 3, there was a significant effect between the waters of different cationic nature, in the treatments receiving $100 \mathrm{mg}$ of $\mathrm{N} \mathrm{kg}^{-1}$ of soil, in which plants irrigated with waters containing $\mathrm{Na}^{+}$ $\left(\mathrm{S}_{2}\right)$ differed statistically from those that received waters containing $\mathrm{Ca}^{2+}$ and $\mathrm{Na}^{+}+\mathrm{Ca}^{2+}+\mathrm{Mg}^{2+} \quad\left(\mathrm{S}_{3}\right.$ and $\mathrm{S}_{5}$, respectively). For the treatment $\mathrm{S}_{4}$, which had $\mathrm{K}^{+}$in the composition, there was no difference. Comparatively, according to the data in Figure 3, there was an expressive reduction in the dry phytomass of the capitulum in sunflower plants when subjected to irrigation using water containing $\mathrm{NaCl} ; \mathrm{CaCl}_{2} ; \mathrm{KCl} ; \mathrm{NaCl}+\mathrm{CaCl}_{2}+\mathrm{MgCl}_{2}$, in relation to the result of the control treatment $\left(\mathrm{S}_{1}\right)$. Based on the results for dry phytomass of the capitulum, it is inferred that the effect of salinity on sunflower plants, cv. BRS 324, is more related to the variation of $\mathrm{ECw}$ than to the cationic nature of the irrigation water. The decrease in DPC (Figure 3), observed in the present study, reflects the negative effect of both the osmotic and ionic components in the salt stress.

Based on the summary of the analysis of variance for the contrasts of means for DPC (Table 3), there was significant effect for the contrast $\hat{y}_{1}\left(S_{1} v s S_{2} ; S_{3} ; S_{4}\right.$ and $\left.S_{5}\right)$. According to Table 4, referring to the estimate of the mean for DPC, there was a greater increment $(27.82 \mathrm{~g})$ in DPCin the plants subjected to treatment $S_{1}$, lowest level of water salinity $(0.5$ $\mathrm{dS} \mathrm{m}^{-1}$ ), in comparison to plants irrigated by the treatments

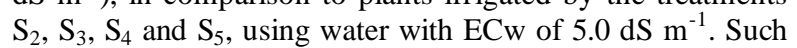
decrease in DPC is attributed to the osmotic effect of the dissolved salts, which reduce the osmotic potential of the soil solution and inhibit the movement of water to the cells, characterizing the water stress, besides the possibility of occurrence of ionic toxicity, nutritional imbalance, or both, due to the excessive accumulation of certain ions in the plant tissues (Flowers, 2004). In an experiment conducted in greenhouse with the sunflower cultivar Embrapa 122/V-2000 irrigated with waters of different salinity levels ( 0.5 to $4.9 \mathrm{dS}$ $\mathrm{m}^{-1}$ ), Nobre et al. (2011) observed that the production of achenes was negatively affected by the increase in the electrical conductivity of the irrigation water.

\section{Materials and Methods}

Localization, experimental procedure, treatments and plant material

The experiment was carried out from November 2014 to January 2015, in pots adapted as lysimeters under field conditions in the experimental area of the Center of Technology and Natural Resources of the Federal University of Campina Grande (CTRN/UFCG), in the municipality of Campina Grande-PB, Brazil, situated at the local geographic coordinates of $07^{\circ} 15^{\prime} 18^{\prime}$ ' $\mathrm{S}, 35^{\circ} 52^{\prime} 28^{\prime}$ ' $\mathrm{W}$ and mean altitude of $532 \mathrm{~m}$.
The experimental design consisted of randomized blocks, arranged in a $5 \times 5$ factorial scheme, with three replicates, corresponding to five combinations of water salinity and cationic nature - S ( $\mathrm{S}_{1}$ - Control; $\mathrm{S}_{2}-\mathrm{NaCl} ; \mathrm{S}_{3}-\mathrm{CaCl}_{2} ; \mathrm{S}_{4}$ $\mathrm{KCl}$ and $\mathrm{S}_{5}-\mathrm{NaCl}+\mathrm{CaCl}_{2}+\mathrm{MgCl}_{2}$ ), in which the ECw used in irrigation was $0.5 \mathrm{dS} \mathrm{m}^{-1}$, for the control treatment, and 5.0 $\mathrm{dS} \mathrm{m} \mathrm{m}^{-1}$, for the other treatments, prepared with different sources of salts according to treatment, in the form of chloride, and five $\mathrm{N}$ doses - N [50; 75; 100; 125 and $150 \mathrm{mg}$ of $\mathrm{N} \mathrm{kg}^{-1}$ of soil, based on the recommendation of Novais et al. (1991)], thus totaling 75 experimental plots, each composed of 1 (one) plant. The ECw level of $5.0 \mathrm{dS} \mathrm{m}^{-1}$ was used to maintain the sunflower plants in an iso-osmotic condition with respect to different cations in the irrigation water. While the lowest level of ECW $\left(0.5 \mathrm{dS} \mathrm{m}^{-1}\right)$ was used as an absolute control in order to verify the effects of saline stress under low and high water salinityconditions.

The different waters used in irrigation were obtained by dissolving different salts, in the water from the local supply, sodium chloride $(\mathrm{NaCl})$, calcium chloride $\left(\mathrm{CaCl}_{2} \cdot 2 \mathrm{H}_{2} \mathrm{O}\right)$, potassium chloride $(\mathrm{KCl})$ and magnesium chloride $\left(\mathrm{MgCl}_{2} \cdot 6 \mathrm{H}_{2} \mathrm{O}\right)$ according to the pre-established treatments, whose amount was determined based on the empirical relationship between the concentration of salts and the electrical conductivity of the water (Richards, 1954). After the waters were prepared, a portable conductivity meter was used to calibrate the $\mathrm{ECw}$; the respective waters were stored in plastic barrels.

This study used seeds of the sunflower cultivar BRS 324, precocious variety with cycle of approximately 100 days, oil content in the seeds varying from 45 to $49 \%$ and mean yield of $1,500 \mathrm{~kg} \mathrm{ha}^{-1}$ (EMBRAPA, 2013).

\section{Establishment and management of the experiment}

Plants were cultivated in pots adapted as lysimeters with capacity for $100 \mathrm{~L}$, filled with a $2.0-\mathrm{kg}$ layer of crushed stone $(<1 \mathrm{~cm})$, followed by $100 \mathrm{~kg}$ of soil material (sandy clay loam), properly pounded to break up clods, classified as eutrophic Grey Argisol, from the district of São José da Mata (Campina Grande-PB), whose physico-chemical characteristics (Table 5) were determined using the methodology of Claessen (1997).

At the bottom of the lysimeters, there was a 4-mm-diameter drain to allow drainage; the upper tip of the drain was involved in a nonwoven geotextile (Bidim OP 30) to avoid obstruction by the soil material and, below the drain, a plastic bottle was placed to collect the drained water, in order to estimate crop water consumption.

Sowing was performed on November 2, 2014, by planting 10 seeds equidistantly, at the depth $0.04 \mathrm{~m}$. At 18 days after sowing (DAS), the first thinning was performed, leaving only three plants per plot, i.e., those with best vigor and, at 34 DAS, a new thinning was performed to leave only one plant per pot.

Phosphate, potassium and nitrogen fertilization was based on the recommendation of Novais et al. (1991). Phosphorus was applied in three intervals, $2 / 3$ as basal dose, corresponding to $125 \mathrm{~g}$ of single superphosphate, and $1 / 3$ divided into 2 equal applications via fertigation, corresponding to $9.62 \mathrm{~g}$ of monoammonium phosphate, at 10 and 20 days after emergence (DAE). Potassium fertilization, along with the nitrogen, was applied as top-dressing via fertigation divided into 3 applications in intervals of 10 days, from $10 \mathrm{DAE}$ on. Each application used 8.62 gof potassium chloride and the treatment $\mathrm{N}_{3}\left(100 \mathrm{mg}\right.$ of $\mathrm{N} \mathrm{kg}^{-1}$ of soil) used $4.85 \mathrm{~g}$ of urea. It should be highlighted that the first 2 
applications aimed to complement the $\mathrm{N}$ supplied by the MAP and $7.41 \mathrm{~g}$ of urea in the last application, following the pre-established treatments.

The soil was maintained at field capacity through daily irrigations, the volume to be applied was based on the water consumption obtained through difference between the volume applied and drained in the previous irrigation, plus a leaching fraction of 0.10 (Lima, 2014).

\section{Traits measured}

At 56 DAS, the physiological parameters of the sunflower were evaluated through the determination of stomatal conductance $(g s)$ (mol of $\mathrm{H}_{2} \mathrm{O} \mathrm{m}^{-2} \mathrm{~s}^{-1}$ ), transpiration $(E)$ $\left(\mathrm{mmol} \mathrm{H} \mathrm{O} \mathrm{m}^{-2} \mathrm{~s}^{-1}\right), \mathrm{CO}_{2}$ assimilation rate $(A)\left(\mu \mathrm{mol} \mathrm{m} \mathrm{m}^{-2} \mathrm{~s}^{-1}\right)$ and internal $\mathrm{CO}_{2}$ concentration $\left(\mu \mathrm{mol} \mathrm{m} \mathrm{m}^{-2} \mathrm{~s}^{-1}\right)(\mathrm{Ci})$ in the third leaf counted from the apex, using a portable device for analyses of gas exchanges through infrared (IRGA), ("LCPro+" ,ADC BioScientific Ltda.). These data were used to quantify the water use efficiency (WUE) $(A / E)\left[\left(\mu \mathrm{mol} \mathrm{m}{ }^{-2}\right.\right.$ $\left.\mathrm{s}^{-1}\right)\left(\mathrm{mol} \mathrm{H}_{2} \mathrm{O} \mathrm{m}^{-2} \mathrm{~s}^{-1}\right)^{-1}$ ] (Konrad et al., 2005; Melo et al., 2009).

The internal capitulum diameter (ICD) was evaluated by measuring, with a millimetric ruler, the horizontal and vertical diameters to obtain the arithmetic mean. For the variables phytomass of the capitulum with achenes (PCA) and dry phytomass of the capitulum (DPC), the material was stored in paper bags and dried in a forced-air oven maintained at $65{ }^{\circ} \mathrm{C}$ until constant weight. The material was weighed on a precision scale $(0.01 \mathrm{~g})$.

\section{Statistical analysis}

The obtained data were subjected to analysis of variance through the F test; when significant, orthogonal contrasts and test of comparison of means (Tukey at 0.05 probability level) was used for the factor "cationic nature of the water" and for the contrasts between the means of the treatments, regression analysis for the "N doses", the statistical software SISVARESAL (Ferreira, 2011) was used. The contrasts were defined as follows: $\hat{y}_{1}\left(S_{1}\right.$ vs $\left.S_{2} ; S_{3} ; S_{4} ; S_{5}\right) ; \hat{y}_{2}\left(S_{2}\right.$ vs $\left.S_{3}\right) ; \hat{y}_{3}\left(S_{2}\right.$ vs $\left.S_{4}\right)$; $\hat{\mathrm{y}}_{4}\left(\mathrm{~S}_{5} \mathrm{vs} \mathrm{S}_{2} ; \mathrm{S}_{3} ; \mathrm{S}_{4}\right)$.

\section{Conclusion}

The cationic nature of the irrigation water causes negative effects on gas exchanges, especially on stomatal conductance and $\mathrm{CO}_{2}$ assimilation rate, of the sunflower cv. BRS 324, at 56 DAS;Among the evaluated cations, potassium promotes the highest values of stomatal conductance and $\mathrm{CO}_{2}$ assimilation rate of the sunflower cv. BRS 324, at 56 DAS; Irrigation water salinity negatively affects the production components of the sunflower cv. BRS 324, regardless of the cation present in the irrigation water.

\section{Acknowledgements}

The authors thank National Council for Scientific and Technological Development (CNPq), the National Institute of Science and Technology in Salinity (INCTSal) and Coordination for the Improvement of Higher (CAPES) for financial support and the grant of scholarship.

\section{References}

Backes RL, Souza AM, Balbinot Junior AA, Gallotti GJM, Alvimar Bavaresco A (2008) Desempenho de cultivares de girassol em duas épocas de plantio de safrinha no Planalto Norte Catarinense. Sci Agra. 9:41-48.

Barhoumi Z, Atia A, Rabhi M, Djeball W, Abdelly C, Smaoui A (2010) Nitrogen and $\mathrm{NaCl}$ salinity effects on the growth and nutrient acquisition of the grasses Aeluropus littoralis, Catapodium rigidum, and Brachypodium distachyum. J Plant Nutr Soil Sci. 173:149-157.

Biscaro GA, Machado JR, Tosta MDAS, Mendonça V, Soratto RP, Carvalho LA (2008) Adubação nitrogenada em cobertura no girassol irrigado nas condições de Cassilândia-MS. Ciênc Agrotec. 32:1366-1373.

Britto DT, Kronzucker HJ (2002) $\mathrm{NH}_{4}^{+}$toxicity in higher plants: a critical review. J Plant Physiol. 159:567-584.

Cavalcanti MLF, Fernandes PD, Gheyi HR, Barros Júnior G, Soares FAL, Siqueira EC (2005) Tolerância da mamoneira BRS 149 à salinidade: Germinação e características de crescimento. Rev Bras Eng Agríc Ambient. 9:57-61.

Claessen MEC (Org.) (1997) Manual de métodos de análise de solo. 2.ed. rev. atual. Rio de Janeiro: Embrapa-CNPS. 212p. (Embrapa-CNPS. Documentos, 1).

EMBRAPA-Empresa Brasileira de Pesquisa Agropecuária (2013) Cultivar de girassol BRS 324: Variedade com alto teor de óleo e precocidade. EMBRAPA Soja. (Folder).

Esteves BS, Suzuki MS (2008) Efeito da salinidade sobre as plantas. Ecologia Bras. 12:662-679.

Ferreira DF (2011) SISVAR: A computer statistical analysis system. Ciênc Agrotec. 35:1039- 1042.

Flexas J, Ribas-Carbó M, Diaz-Espejo A, Galmés J, Medrano $\mathrm{H}$ (2008) Mesophyll conductance to $\mathrm{CO}_{2}$ : current knowledge and future prospects. Plant Cell Environ. 31:602-628.

Flowers TJ (2004) Improving crop salt tolerance. J Exp Bot. 55:307-319.

Graciano ESA, Nogueira RJMC, Lima DRM, Pacheco CM, Santos RC (2011) Crescimento e capacidade fotossintética da cultivar de amendoim BR 1 sob condições de salinidade. Rev Bras Eng Agríc Ambient. 15: 794-800.

Gurgel MT, Fernandes PD, Gheyi HR, Santos FJ de S, Bezerra IL, Nobre RG (2003) Estresse salino na germinação e formação de porta-enxerto de aceroleira. Rev Bras Eng Agríc Ambient. 7:31-36.

Konrad MLF, Silva JAB, Furlani PR, Machado EC (2005) Trocas gasosas e fluorescência da clorofila em seis cultivares de cafeeiro sob estresse de alumínio. Bragantia. 64:339-347.

Kurban H, Saneoka H, Nehira K, Adilla R, Premachandra GS, Fujita K (1999) Effect of salinity on growth, photosynthesis and mineral composition in leguminous plant Alhagi pseudoalhagi (Bieb.). Soil Sci Plant Nutr. 45:851-862.

Kusvuran S (2012) Effects of drought and salt stresses on growth, stomatal conductance, leaf water and osmotic potentials of melon genotypes (Cucumis melo L.). Afr J Agric Res. 7:775-781.

Leonardo M, Broetto F, Bôas RLV, Almeida RS, Godoy LJG, Marchese JÁ (2003) Estresse salino induzido em plantas de pimentão e seus efeitos na produção de frutos. Hortic Bras. 21:1-4.

Lima GS de (2014) Salinidade e natureza catiônica da água de irrigação na morfofisiologia e produção da mamoneira. 2014. 155 f. Tese (Doutorado em Engenharia Agrícola). Universidade Federal de Campina Grande, Centro de Tecnologia e Recursos Naturais. Campina Grande, PB.

Marrenco Centeno CR, Santos JB dos, Xavier DA, Azevedo CAVde, Gheyi HR (2014) Componentes de produção do girassol Embrapa 122-V2000 sob salinidade da água e 
adubação nitrogenada. Rev Bras Eng Agríc Ambient. 18:39-45.

Melo ASde, Silva Júnior CDda, Fernandes PD, Sobral LF, Brito MEB, Dantas JDM (2009) Alterações das características fisiológicas da bananeira sob condições de fertirrigação. Ciênc Rural. 39:733-741.

Meloni DA, Oliva MA, Martinez CA, Cambraia J (2003) Photosynthesis and activity of superoxidedismutase, peroxidase and glutathione reductase in cottonundersalt stress. Environ Exp Bot. 49:69-76.

Miller AJ, Cramer MD (2004) Root nitrogen acquisition and assimilation. Plant Soil. 274:3-6.

Munns R, Tester M (2008) Mechanisms of salinity tolerance. Annu Rev Plant Biol. 59:651-681.

Munns R, Husain S, Rivelli AR, Richard AJ, Condon AG, Megan PL, Evans SL, Schachtman, DP, Hare RA (2002) Avenues for increasing salt tolerance of crops, and the role of physiologically based selection traits. Plant Soil. 247:93105.

Neves ALR, Lacerda CF, Guimarães FVA, Hernandez FFF, Silva FB, Prisco JT, Gheyi HR (2009) Acumulação de biomassa e extração de nutrientes por plantas de feijão-decorda irrigadas com água salina em diferentes estádios de desenvolvimento. Ciênc Rural. 39:758-765.

Nobre RG, Gheyi HR, Correia KG, Soares FAL, Andrade L (2010) Crescimento e floração do girassol sob estresse salino e adubação nitrogenada. Rev Ciênc Agron. 41:358365.

Nobre RG, Gheyi HR, Soares FAL, Cardoso JAF (2011) Produção de girassol sob estresse salino e adubação nitrogenada. Rev Bras Ciênc Solo. 35:929-937.

Novais RF, Neves JCL, Barros NF (1991) Ensaio em ambiente controlado. In: Oliveira AJ (ed.) Métodos de pesquisa em fertilidade do solo. Brasília: Embrapa-SEA. p.189-253.

Oliveira FA, Oliveira FRA, Campos MS, Oliveira MKT, Medeiros JF, Silva MP (2010) Interação entre salinidade e fontes de nitrogênio no desenvolvimento inicial da cultura do girassol. Rev Bras Ciênc Agrárias. 5:479-484.

Pereira VC, Amabile RF, Carvalho CGP de, Barbosa F de S, Ribeiro Júnior WQ (2008) Girassol em safrinha no Cerrado do Distrito Federal: desempenho de genótipos em 2006. In: Simpósio Nacional Cerrado, 9.; Simpósio Internacional Savanas Tropicais, 2., Brasília, DF. Desafios e estratégias para o equilíbrio entre sociedade, agronegócio e recursos naturais: Anais... Planaltina: Embrapa Cerrados. 1 CDROM.
Richards LA (1954) Diagnosis and improvement of saline and alkali soils. Washington: U. S. Department of Agriculture. 160p. (USDA, Agriculture Handbook, 60).

Sousa AEC, Lacerda CF de, Gheyi HR, Soares FAL, Uyeda CA (2012b) Teores de nutrientes foliares e respostas fisiológicas em pinhão manso submetido a estresse salino e adubação fosfatada. Rev Caatinga. 25:144-152.

Sousa AEC, Silveira JAG, Gheyi HR, Lima Neto MC, Lacerda CF, Soares FAL (2012a) Trocas gasosas e conteúdo de carboidratos e compostos nitrogenados em pinhão-manso irrigado com águas residuária e salina. Pesq Agropec Bras. 47:1428-1435.

Souza LHB (2010) Crescimento e desenvolvimento da cultura do girassol no Recôncavo da Bahia. 100f. (Mestrado em Fitotecnia). Universidade Federal do Recôncavo da Bahia (UFRB), Cruz das Almas, Bahia.

Taiz L, Zeiger E. Fisiologia vegetal. 5. ed. Porto Alegre: Artmed, 2013.819p.

Wanderley JAC, Araújo Filho JB, Souza JS, Alves LS, Maracajá PB (2010) Efeito de doses de rejeito de caulim em solo sódico no desenvolvimento inicial da mamoneira (Ricinus communis L.). Rev Verde de Agroec e Desenvolv Sustent. 5:26-38. 